\title{
Atmospheric pollutants and their association with olive and grass aeroallergen concentrations in Córdoba (Spain)
}

\author{
Maria Pilar Plaza ${ }^{1,2}$ (1) $\cdot$ Purificación Alcázar ${ }^{2} \cdot$ José Oteros $^{2,3} \cdot$ Carmen Galán $^{2}$ \\ Received: 16 February 2020 / Accepted: 6 August 2020 / Published online: 13 August 2020 \\ (C) The Author(s) 2020, corrected publication 2021
}

\begin{abstract}
Cumulative data indicate that pollen grains and air pollution reciprocally interact. Climate changes seem also to influence pollen allergenicity. Depending on the plant species and on the pollutant type and concentration, this interaction may modify the features and metabolism of the pollen grain. Previous results revealed a significant positive correlation between pollen and aeroallergen, even using two different samplers. However, some discrepancy days have been also detected with low pollen but high aeroallergen concentrations. The main aim of the present paper is to find how the environmental factors, and specially pollutants, could affect the amount of allergens from olive and grass airborne pollen. Pollen grains were collected by a Hirst-type volumetric spore trap. Aeroallergen was simultaneously sampled by a low-volume Cyclone Burkard sampler. Phl p 5 and Ole e 1 aeroallergen were quantified by double-sandwich ELISA test. The data related to air pollutants, pollen grains, and aeroallergens were analyzed with descriptive statistic. Spearman's correlation test was used to identify potential correlations between these variables. There is a significant positive correlation between aeroallergens and airborne pollen concentrations, in both studied pollen types, so allergen concentrations could be explained with the pollen concentration. The days with unlinked events coincide between olive and grass allergens. Nevertheless, concerning to our results, pollutants do not affect the amount of allergens per pollen. Even if diverse pollutants show an unclear relationship with the allergen concentration, this association seems to be a casual effect of the leading role of some meteorological parameters.
\end{abstract}

Keywords Pollutants $\cdot$ Aeroallergens $\cdot$ Pollen $\cdot$ Olive $\cdot$ Grass $\cdot$ Climate change

The original online version of this article was revised due to a retrospective Open Access order.

Responsible editor: Lotfi Aleya

Electronic supplementary material The online version of this article (https://doi.org/10.1007/s11356-020-10422-x) contains supplementary material, which is available to authorized users.

Maria Pilar Plaza

maria.plaza@tum.de

1 Chair and Institute of Environmental Medicine, UNIKA-T, University of Augsburg - Technical University of Munich (TUM) and Helmholtz Zentrum München, Neusässer Str. 47, 86156 Augsburg, Germany

2 Department of Botany, Ecology and Plant Physiology, University of Córdoba (UCO), Córdoba, Spain

3 Center of Allergy \& Environment (ZAUM), Member of the German Center for Lung Research (DZL), Technische Universität München/ Helmholtz Center, Munich, Germany

\section{Introduction}

Air pollution is a mixture of diverse particles and gasses in the air. Car emissions, chemicals from factories, dust, and also pollen grains and mold spores may be suspended as particles. Air pollutants, especially those related to climate change, will affect the immune reaction (Annesi-Maesano, 2016; Eguiluz-Gracia et al., 2020; Sheehan et al., 2017), when modifying the pollen grains, causing an inflammatory answer in the airways and an increased predisposition to aeroallergen exposure (Provost et al. 2014), such as asthma and allergic rhinitis (Noyes et al. 2009).

Atmospheric pollution plays a key role in all age set health (Anderson et al. 2013; Crouse et al. 2015; Fernández-Navarro et al. 2017). It has become obvious that urban individuals have more severe symptoms of respiratory allergies related with those living in rural areas (D'Amato et al. 2010). In cities, with high pollutant levels, biomass of vegetation and flowering seem to increase and therefore, rising airborne pollen concentration and thus pollinosis (Peden and Reed 2010; Schmidt 2016; Shea et al. 2008). 
Numerous studies have investigated the effects of shortterm exposure to air pollutants on respiratory symptoms and a positive association was found between exposure to ozone, carbon monoxide, nitrogen dioxide, sulfur dioxide, and particulate matter of $10 \mu \mathrm{m}$ with asthma-related hospitalizations (Kim et al., 2015; Oduber et al., 2019; Oh, 2018; Zhang et al., 2015).

Effects of pollution on the worldwide bioaerosols are already known and studied (Bartra et al. 2007; Jenerowicz et al. 2012, Sedghy et al. 2018). This interaction can take place through a number of mechanisms; chemical pollutants could facilitate pollen allergen release, act as adjuvants to excite IgEmediated responses, transform allergenic potential, and develop the expression of some allergens in pollen grains (Sedghy et al. 2018). On the other hand, atmospheric pollutants might cause the following direct effects on pollen (Sénéchal et al. 2015): diminution in viability and germination, variation of the physicochemical features of the pollen grain surface, modification in the allergenic potential, and adjuvant effect increasing their potential health risks. Pollutants and climate change affect not only pollen allergenicity (D'Amato et al., 2015; Naclerio et al., 2020), but also allergen concentration. Rogerieux et al. (2007) detected a decrease in allergen content in pollen samples treated with a mix of $\mathrm{NO}_{2} / \mathrm{O}_{3}$ or $\mathrm{NO}_{2} / \mathrm{SO}_{2}$. Short-term exposure of oak pollen to high concentrations of $\mathrm{SO}_{2}$ or $\mathrm{NO}_{2}$ significantly increases their fragility and disruption, leading to subsequent release of pollen cytoplasmic granules into the atmosphere (Ouyang et al. 2016).

Cumulative data indicate that pollen grains and air pollution reciprocally interact. Depending on the plant species and on the pollutant type and concentration, this interaction may modify the vitality, shape, size, physiologic features, and metabolism of the pollen grain (Malayeri et al. 2012). In recent studies, air pollution induced structural changes in macromolecules of mugwort pollen (Chen et al., 2020; Depciuch et al., 2016), which might contribute to an increment prevalence of allergic diseases in urban environs.

Global warming resulting climate change has been also causing indirect effects, such as an increase in the number of air pollutants as well as expansion of allergens (Cecchi et al. 2017; D'Amato et al. 2016; McMichael et al. 2006). Tashpulatov et al. (2004) found that increasing temperature determines higher allergen contents in birch pollen.

It has been shown that pollutants, gaseous, and/or particulate are also carried on allergenic particles as pollen or fungal spores (Behrendt et al. 1997). Moreover, air pollution possibly will have indirect effects by combining aeroallergens with some particles, such as diesel particles (Chehregani and Kouhkan 2008). In fact, some researchers use the neologism "polluen" (LAAIDI et al. 2002; Laaidi et al. 2011; Peltre 1998; Sénéchal et al. 2015) to point out this specific atmospheric material. It could contain water-soluble allergens or non-water-soluble ones and have many shapes and sizes. They can act as carriers of allergens and help their dispersion and access to the airways (D'Amato et al. 2007). Several researchers identified relevant allergens carried by airborne particles released from pollen of grass (Abou Chakra et al. 2012), ragweed (Pazmandi et al. 2012), and cypress (Shahali et al. 2009a), under rain or on in vitro treatment. Modification of pollen coating by air pollutants should be accounted for in further studies on the effect of pollution on germination and on allergenicity (Naas et al. 2016).

Additionally, air pollution and climate changes might make a greater expression of allergenic molecules in pollen grains attributable to adaptation of plants to abiotic stress (Mousavi et al. 2019; Shahali and Dadar 2018). Pollutants and climate changes are among the main plant stressors, especially in urban areas. Therefore, airborne pollen is today considered a sensitive indicator of plant climate change (Oteros et al. 2015; Recio et al. 2018). Numerous studies are focusing on airborne pollen concentration trends (Galán et al. 2016; Smith et al. 2009; Sofiev et al. 2015; Ziello et al. 2012) or in paleobotany studies that indicate how sensitive the plants are to temperature changes (Nolan et al. 2018).

These environmental factors could enhance the quantity and prompt chemical modifications of allergens, increase oxidative stress in the human organism, and trigger allergic reactions. Specially, air pollutants can play a role of adjuvants and modify the immunogenicity of allergenic proteins, whereas atmospheric abundance and human exposure to bioaerosol and aeroallergens are affected by climate change (ReinmuthSelzle et al. 2017).

One of these stress inducers is ozone, known to induce NADPH increase in ragweed pollen, which in turn generates reactive oxygen species (Pasqualini et al. 2011).

Previous studies in Córdoba (Spain) showed year-to-year differences in timing and intensity of Poaceae and olive pollen season vs. aeroallergens (Plaza et al. 2016a, b). These results revealed a significant positive correlation between these two variables, even using two different samplers (Plaza et al. 2017). However, some aeroallergens in the absence of airborne pollen were recorded before and after the pollen season. Pollen allergen potency (PAP) (Galán et al. 2017) value is also pretty different between both pollen types; on average, PAP is $50 \mathrm{pg} / \mathrm{m}^{3}$ in grasses but $15 \mathrm{gg} / \mathrm{m}^{3}$ in olive. Some discrepancy days have been also detected with low pollen but high aeroallergen concentrations.

Córdoba is also among the 200 municipalities in Spain whose air contains higher levels of exposure to carcinogenic pollutants of industrial origin (http://www.juntadeandalucia. es/temas/medio-ambiente/emisiones/calidad.html).

The main aim of the present paper is to find how the environmental factors affect the amount of allergens in the airborne pollen of olive and grasses. We specially focus on the impact of pollutants, such as $\mathrm{O}_{3}, \mathrm{NO}_{2}$, and $\mathrm{SO}_{2}$ on the PAP of the pollen as they are suggested as key factors by several 
authors (Malayeri et al. 2012; Sénéchal et al. 2015; Shahali et al. 2009a). We also focus our attention to explain the term "unusual episodes," i.e., the days during that the PAP is extremely high, because they could have a special clinical relevance.

\section{Methods}

\section{Airborne pollen and aeroallergen sampling}

In flowering season, Poaceae and Olea airborne pollen and their major aeroallergen proteins ( $\mathrm{Phl} \mathrm{p} 5$ and Ole e 1) were sampled during three consecutive years (2012-2014) in Córdoba ( $37^{\circ} 53^{\prime} 0^{\prime \prime} \mathrm{N}$ y $44^{\circ} 5^{\prime} 0^{\prime \prime} \mathrm{W} ; 123 \mathrm{~m}$ a.s.1.), a medium-sized city in the southwestern Iberian Peninsula.

Pollen grains were detected by a Hirst-type volumetric spore trap (Hirst 1952), with methodology suggested by the Spanish Aerobiology Network (REA) in Management and Quality Manual (Soldevilla et al. 2007) and the European Aerobiology Society (EAS) (Galán et al. 2014). At the same time, aeroallergen proteins were sampled by a low-volume Cyclone Burkard sampler (Emberlin 1995), following the method by Takahashi et al. (2001) and adapted by MorenoGrau et al. (2006). Afterwards, aeroallergen particles were quantified by double-sandwich ELISA test (Plaza et al. 2016a, 2016b; Rodríguez-Rajo et al. 2011; Moreno-Grau et al. 2006; Arilla et al. 2002, 2005, 2006).

The pollen season was defined following suggestions from Velasco-Jiménez et al. (2013), considering the flowering intensity and flowering behavior. For olive pollen season, the first day started on which 50 or more pollen grains $/ \mathrm{m}^{3}$ were recorded (Plaza et al., 2016b). For grass pollen season, the first day started on which 10 or more pollen grains $/ \mathrm{m}^{3}$ were collected (Plaza et al., 2016a). The end date was, both cases, the last day with these daily values or less for five consecutive days.

We considered in the analysis some "unusual episodes," days with particularly high pollen allergen potency (PAP$\rho g /$ pollen grain), i.e., greater allergens per pollen than double the average.

\section{Meteorological data}

Meteorological data were provided by the Andalusia Regional Government Agroclimatic Information Network, with station located on the outskirts of Cordoba City (coordinates $37^{\circ} 51^{\prime}$ $\left.25^{\prime \prime} \mathrm{N}, 04^{\circ} 48^{\prime} 10^{\prime \prime} \mathrm{W}\right)$.

\section{Air pollution data}

The Network for Monitoring and Control of Atmospheric Pollution in Andalusia, which is responsible for analyzing the presence of pollutants in the atmosphere, provided the pollution data. The Net was composed of 91 measuring stations and 12 meteorological towers and is responsible for detecting possible emergency situations.

Measurement item in relation to the atmospheric environmental standards include sulfur dioxide $\left(\mathrm{SO}_{2}\right)$, carbon monoxide $(\mathrm{CO})$, nitrogen dioxide $\left(\mathrm{NO}_{2}\right)$, fine dust $\left(\mathrm{PM}_{10}\right)$, and ozone $\left(\mathrm{O}_{3}\right)$, which are measured once every hour. The daily average of these data from the nearest station to the samplers (Lepanto Station coordinates $37^{\circ} 53^{\prime} 29^{\prime \prime} \mathrm{N}, 04^{\circ} 45^{\prime} 51^{\prime \prime} \mathrm{W}$ ) was used.

\section{Statistical analysis}

The data related to air pollutants $\left(\mathrm{SO}_{2}, \mathrm{CO}, \mathrm{NO}_{2}, \mathrm{PM}_{10}, \mathrm{O}_{3}\right)$, pollen grains, and aeroallergens were analyzed with descriptive statistic. Spearman's correlation test was used to identify potential correlations between these variables and meteorological parameters, considering the pollen seasons for each pollen type. Calculations were performed using the SPSS version 14 software package for Windows and R (R Core Team, 2013; RStudio Team, 2020).

\section{Results}

Aeroallergen and airborne pollen showed significant correlation (Fig. 1). However, some discrepancy days have been detected not only with low pollen and high aeroallergen concentrations but also with a PAP greater than double the average (mean in grasses: 44.58, mean in olive: 15.2). These "unusual episodes" largely matched in both olive and grasses in same dates (Table 1, figures in the Supplementary material).

The average levels of $\mathrm{SO}_{2}, \mathrm{PM}_{10}, \mathrm{NO}_{2}, \mathrm{CO}$, and $\mathrm{O}_{3}$, during 2012-2014, are shown in Table 2. Except for $\mathrm{NO}_{2}$, the average measures from all pollutants are lower during 2013 and higher percentages on days with great values were collected for all the pollutants during 2012 (Fig. 2). The highest concentrations in all cases are with a southwest wind. Regarding the daily pollutant concentration, it seems to be higher during the spring season (from 04-01 to 05-15) for $\mathrm{CO}$ and $\mathrm{NO}_{2}$ than during the early summer (from 05-16 to 07-01), with greater concentration for $\mathrm{SO}_{2}, \mathrm{PM}_{10}$, and $\mathrm{O}_{3}$ (Supplementary material).

Tropospheric ozone $\left(\mathrm{O}_{3}\right)$ shows high levels in our study area, as 40 days during the pollen season period from 2012 to 2014 exceeded the average value limit $160 \mu \mathrm{g} / \mathrm{m}^{3}$ in an hour, concentration with registered negative health effects (WHO, 2000). These days are concentrated especially in June between 16.00 and 17.00. Regarding nitrogen dioxide $\left(\mathrm{NO}_{2}\right)$, the limit value per hour has been exceeded only in the 18th of June 2012 (from 9.00 to 10.00) with measures greater than the reference limit value, $200 \mu \mathrm{g} / \mathrm{m}^{3}$. 
Table 1 Unusual days during pollen season in studied period 2012-2014

\begin{tabular}{lrrrrr}
\hline Date & PAP grasses & PAP olive & \multicolumn{1}{l}{ Date } & PAP grasses & PAP olive \\
\hline $2012-04-06$ & 149.87 & 51.36 & $2012-04-23$ & 119.16 & - \\
$2012-04-08$ & 147.83 & - & $2012-04-24$ & 213.63 & - \\
$2012-04-09$ & 127.52 & 138.55 & $2012-04-25$ & 93.44 & 106.24 \\
$2012-04-10$ & 173.63 & - & $2012-04-29$ & 1179.57 & 50.36 \\
$2012-04-11$ & 378.69 & - & $2012-04-30$ & 408.91 & 72.08 \\
$2012-04-13$ & 325.99 & 35.99 & $2012-05-01$ & 140.46 & 134.24 \\
$2012-04-15$ & 278.83 & 31.05 & $2012-05-04$ & 699.95 & 113.56 \\
$2012-04-16$ & 235.40 & 161.88 & $2012-05-19$ & - & 50.46 \\
$2012-04-18$ & 129.87 & & $2013-04-25$ & 138.29 & - \\
$2012-04-19$ & 375.44 & & $2013-04-30$ & 89.75 & - \\
$2012-04-20$ & 91.93 & 63.28 & $2014-04-11$ & 119.84 & 707.95 \\
$2012-04-21$ & 191.29 & - & $2014-06-08$ & - & 87.49 \\
$2012-04-22$ & 142.68 & - & $2014-06-11$ & - & 85.11 \\
\hline
\end{tabular}

Concerning the correlation between biological particles and pollutants, it has been observed that PAP and all the considered parameters have a vague relationship in both pollen types (Figs. 3 and 4). None of the pollutant shows a significant correlation for both pollen types, but $\mathrm{PM}_{10}$ seems to be lower when high PAP is reached. Allergen concentration is higher in relation to pollen when the relative humidity and rainfall increase, and so, it coincides with days with low pollen concentration and $\mathrm{PM}_{10}$.

Since we observe large differences in sporadic days, we present two groups, one that includes the days with expected values and the other with non-normal values. And we investigated the correlation of these two groups with the different variables.

Figures 5 and 6 show the different parameters studied separately in normal days with respect to the so-called unusual episodes (high PAP) in order to see possible differences between them. These events seem to occur in rainy or high humidity days, since they coincide with rainy days $70 \%$ of the times. The results indicate that in both olives and grasses, the parameters that have a significant relationship to the ratio allergens/pollen are $\mathrm{O}_{3}$ and $\mathrm{PM}_{10}$, though this correlation is negative since it has just been shown that $\mathrm{PM}_{10}$ is low when aeroallergens are high. Regarding meteorological parameters, humidity has significant correlation in both pollen types and temperature just with grasses. We also observed that humidity is especially relevant in unusual days that can be explained as rainy highly humid days with low pollen concentrations due to atmospheric washing but with greater allergen dispersion. In the case of grasses, a significant connection with temperature is found, probably due to the difference in PAP by grass species along the season. The connections of $\mathrm{O}_{3}$ and $\mathrm{PM}_{10}$ with PAP can be the result of the impact of weather conditions.

\section{Discussion}

Pollution seems to produce several noxious effects on pollen grains (Oduber et al. 2019; Sénéchal et al. 2015). In most
Fig. 1 Pollen allergen potency in grass and olive

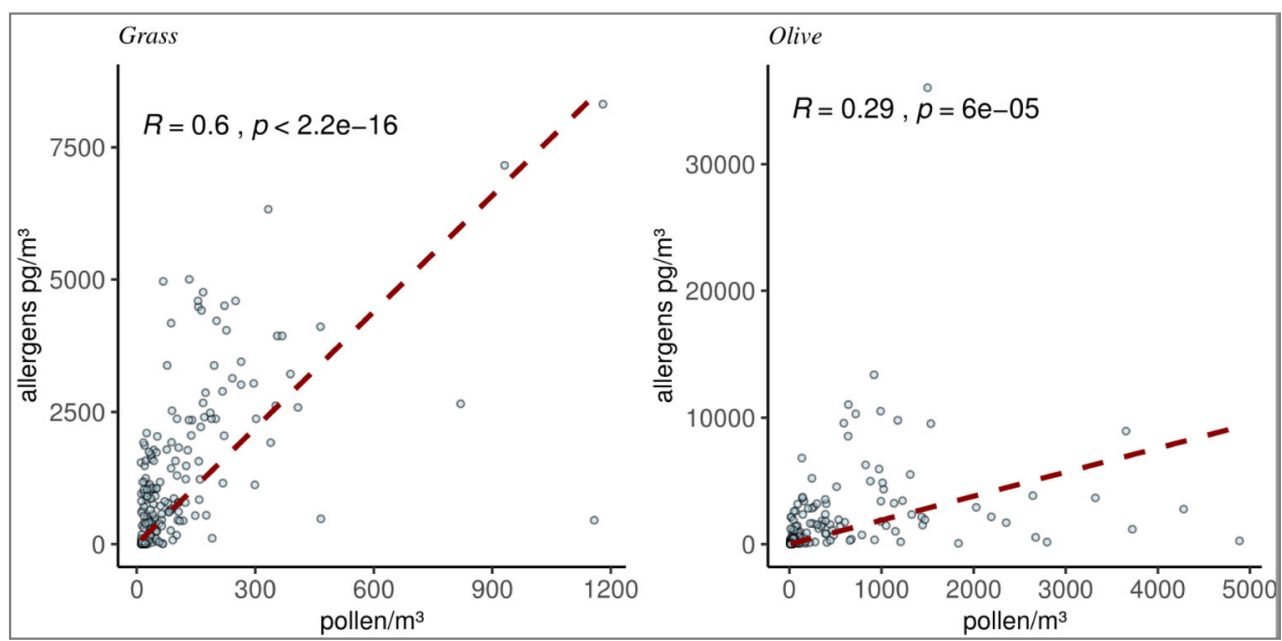


Table 2 Average values of pollutants during the pollen season in period 2012-2014. SD $=$ standard deviation. $\mathrm{SE}=$ standard error of the mean

\begin{tabular}{lllllll}
\hline & Statistics & $\mathrm{SO}_{2}\left(\mu \mathrm{g} / \mathrm{m}^{3}\right)$ & $\mathrm{PM}_{10}\left(\mu \mathrm{g} / \mathrm{m}^{3}\right)$ & $\mathrm{NO}_{2}\left(\mu \mathrm{g} / \mathrm{m}^{3}\right)$ & $\mathrm{CO}\left(\mu \mathrm{g} / \mathrm{m}^{3}\right)$ & $\mathrm{O}_{3}\left(\mu \mathrm{g} / \mathrm{m}^{3}\right)$ \\
\hline 2012 & Mean & 5.33 & 21.36 & 23.16 & 466.52 & 64.95 \\
& Maximum & 14.54 & 128.32 & 158.69 & 913.78 & 97.31 \\
& Minimum & 3.14 & 1.00 & 7.99 & 87.01 & 6.69 \\
& $\mathrm{SD}$ & 1.44 & 16.68 & 26.87 & 287.69 & 21.20 \\
& $\mathrm{SE}$ & 0.15 & 1.73 & 2.80 & 29.99 & 2.21 \\
& Mean & 3.28 & 18.81 & 16.26 & 252.99 & 61.12 \\
& Maximum & 5.66 & 37.28 & 29.11 & 521.24 & 87.48 \\
& Minimum & 2.20 & 2.98 & 6.85 & 40.64 & 36.99 \\
& $\mathrm{SD}$ & 0.60 & 7.74 & 5.00 & 128.75 & 9.54 \\
& $\mathrm{SE}$ & 0.06 & 0.81 & 0.52 & 13.42 & 0.99 \\
& Mean & 4.31 & 20.37 & 15.59 & 427.44 & 67.95 \\
& Maximum & 5.27 & 36.35 & 31.39 & 661.0 & 102.78 \\
& Minimum & 3.40 & 5.95 & 5.76 & 184.2 & 44.99 \\
& $\mathrm{SD}$ & 0.45 & 7.46 & 6.12 & 110.97 & 12.85 \\
$\mathrm{SE}$ & 0.05 & 0.77 & 0.64 & 11.57 & 1.34 \\
\hline
\end{tabular}

species, its pollen in urban areas is more allergenic than pollen in areas less exposed to pollution (D'Amato et al., 2010; Guarnieri and Balmes, 2014), even though some controversial results have been stated, where air pollution exposure does not seem to increase the general risk of sensitization to allergens (Berger et al., 2020; Gruzieva et al., 2012). Nevertheless, all of these studies emphasize the importance of integration environmental factors in the development of allergic diseases (Sbihi et al., 2019).

Most of the studies use correlation analysis between both particles; however, this analysis is not the most accurate for this study since we worked with sporadic days. For that
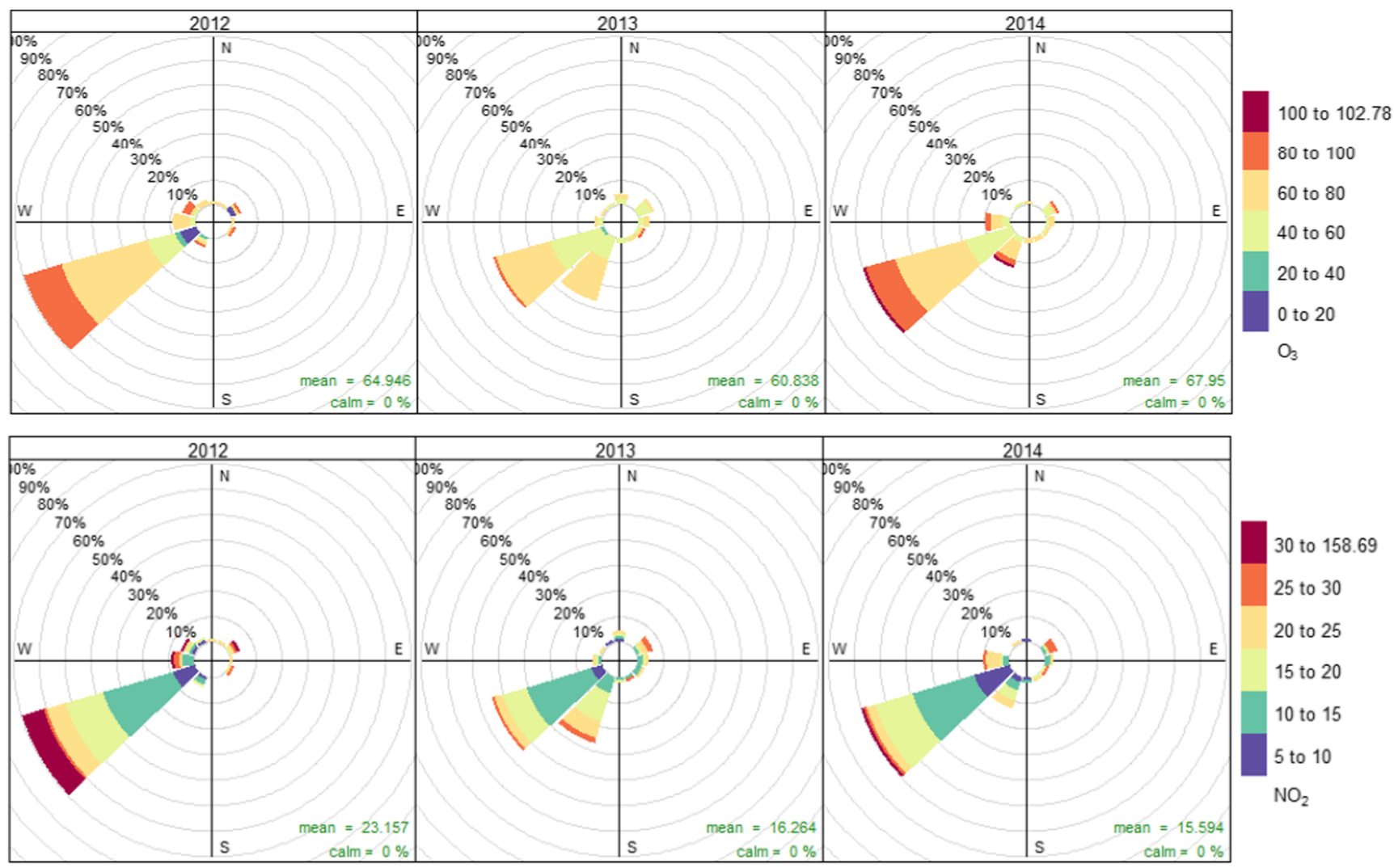

Fig. 2 Frequency of days with the highest percentage of pollutants $\mathrm{O}_{3}$ and $\mathrm{NO}_{2}$, for each year and the prevailing wind direction 


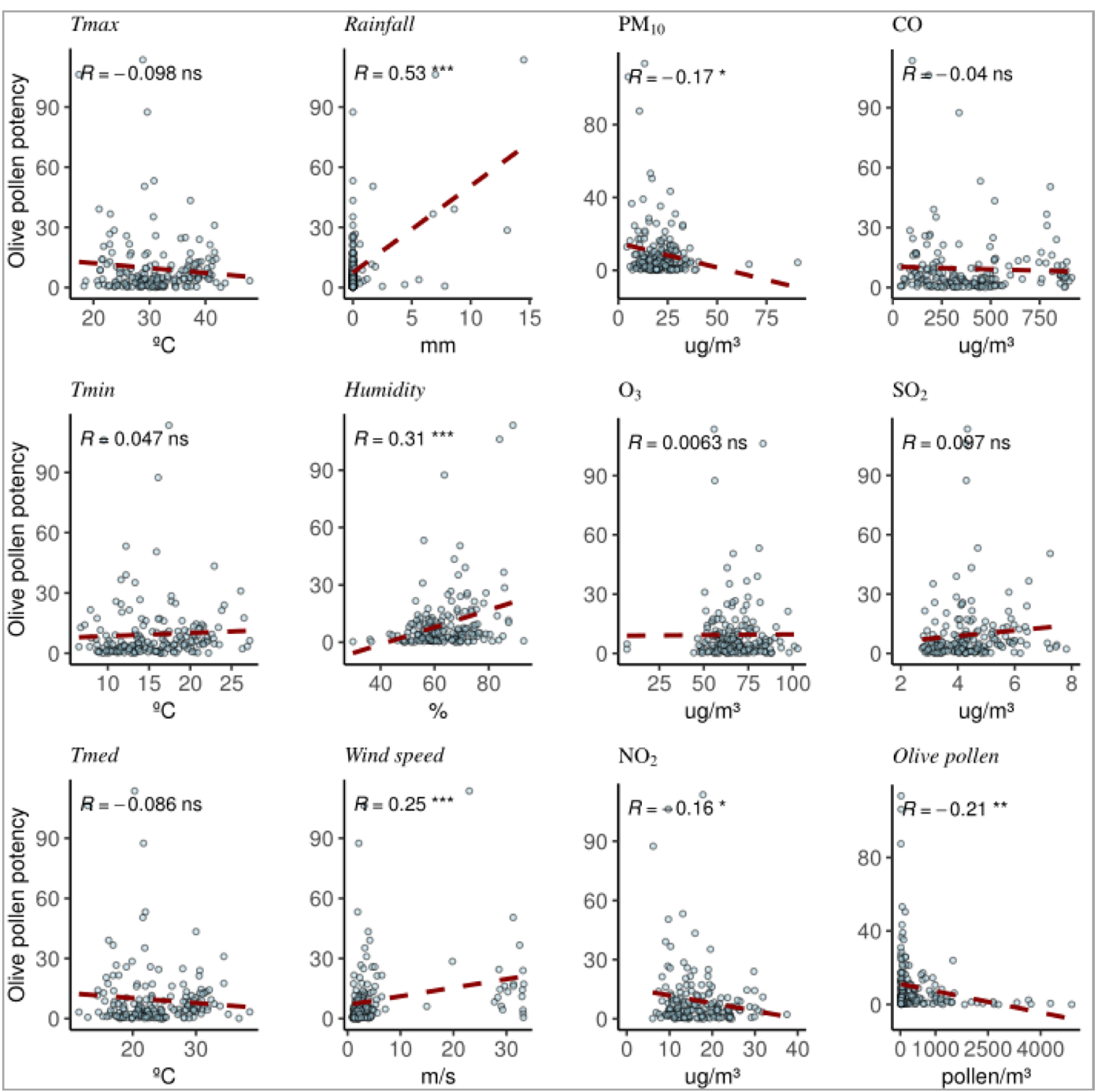

Fig. 3 Olive PAP correlation with the different pollutants and meteorological parameters

reason, we define unusual days, with unexpected allergen concentration per pollen grain.

Regarding our study, there is a significant positive correlation between aeroallergens and airborne pollen concentrations, even using different samplers (Plaza et al. 2017) in both pollen type detections, so allergen concentrations could be explained with the pollen concentration. On the other hand, the days with unlinked events (unusual episodes) coincide between olive and grass allergens. Nevertheless, the role of pollutants is not shown in a clear way but does not seem to have any influence during the unusual episodes, since only $\mathrm{O}_{3}$ and $\mathrm{PM}_{10}$ have a correlation but this is negative. Both $\mathrm{O}_{3}$ and $\mathrm{PM}_{10}$ could be the reflection of rainy days with low amount of particles in the air (Yoo et al., 2014), as $\mathrm{O}_{3}$ is especially low during cloudy days.

Even if we do not find clear facts of the role of pollutants in free allergens, it is known that elemental composition of pollen is very often modified by pollution. Chemical changes on pollen grains are detectable when comparing pollen (Thuja orientalis) from polluted and unpolluted sites (Rezanejad 2009). In this study, it is suggested that some plant defense mechanisms are initiated in pollen affected by airborne particulate matter, adjusting their metabolism so that minimum damage is done due to air pollutants. Such as, the pollen grains collected from polluted zones are smaller and more fragile compared with the low polluted ones. The exine disruption seems to be faster and higher in polluted pollen grains (Duhoux 1982; Shahali et al. 2009b), which can facilitate the release of internal particles such as allergens (Behrendt et al. 1997; Sénéchal et al. 2015). This could mean that in urban areas, having more fragile pollen grains, more allergens are released (Lacroix 2005; Motta et al. 2006) and contribute to an increased pollen allergenicity (Costa et al., 2019) when are exposed to traffic-related air pollutants such as $\mathrm{NO}_{2}$ and 


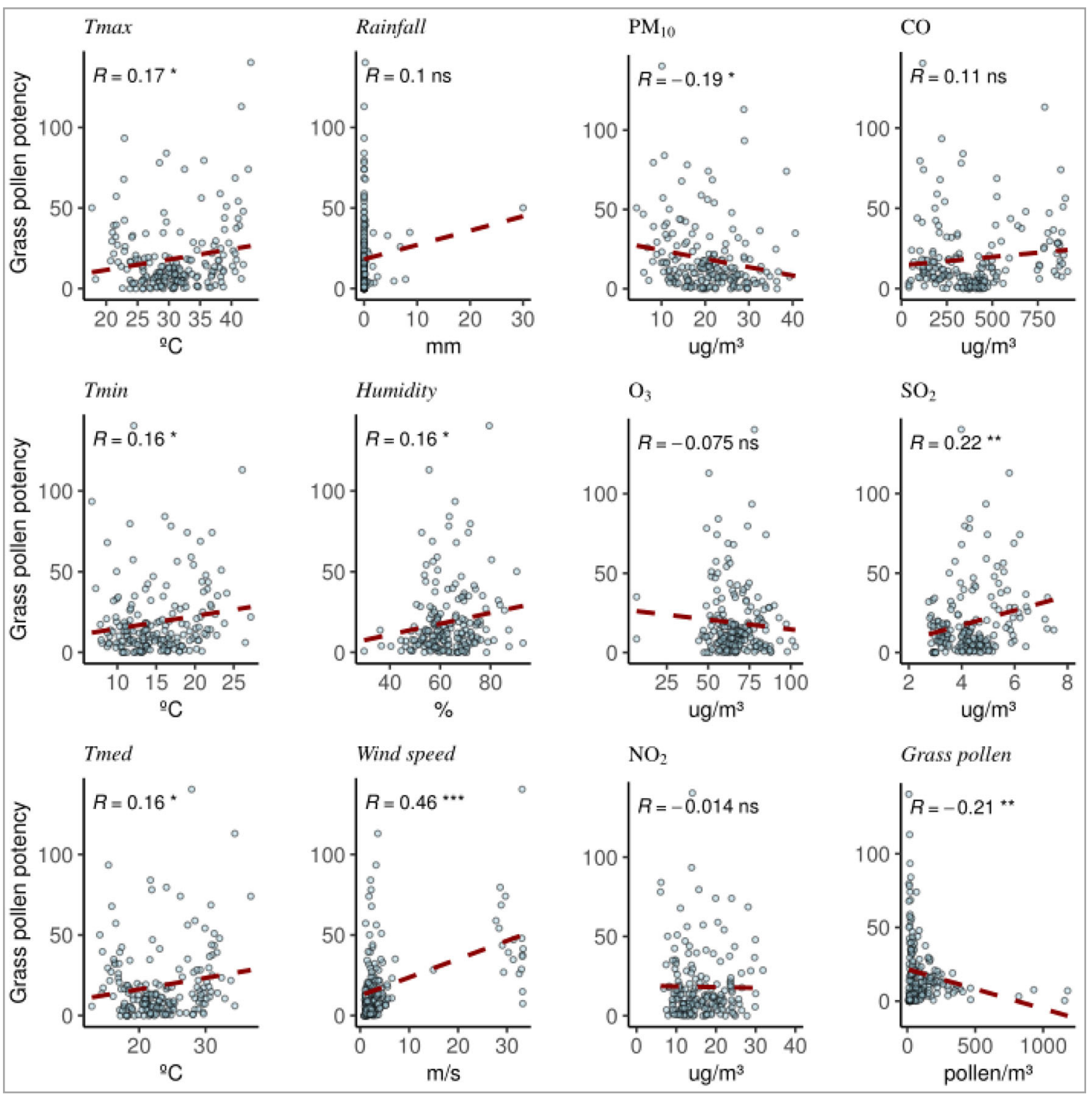

Fig. 4 Grass PAP correlation with the different pollutants and meteorological parameters

$\mathrm{O}_{3}$. For example, Platanus orientalis pollen became swollen after several hours of fumigation with $\mathrm{NO}_{2}$, or $\mathrm{SO}_{2}$ ( $\mathrm{Lu}$ et al. 2014). However, others found no differences between polluted and non-polluted pollen (Kanter et al. 2013). That discrepancy may be caused from differences in the studied pollen grains and the variable amounts of gas pollutants used. Moreover, it has been shown that the humidity also affects pollen in this regard (Buters et al. 2015; Plaza et al. 2016b). However, according to our results, unusual days with low pollen concentration but high allergen concentration do not take place during high peaks of pollutants in the atmosphere.

On the other hand, different modifications induced by air pollution have been studied at protein level. Pollutants play a role in the difference of protein amount and/or the presence or absence of proteins in comparative extracts. For instance, Shahali et al. (2009b) found a reduction in total protein amount on polluted sites as well as a clear decrease of the allergens. On contrast, after exposing different pollen grains to $\mathrm{SO}_{2}, \mathrm{NO}_{2}$, and $\mathrm{O}_{3}$, it shows the most important release of protein material (Thomas et al. 1996) with the most concentrated rate of dust. In other investigations, a significant decrease was found in the protein content in a pollen type exposed to $\mathrm{NO}_{2}$ independently and those exposed to $\mathrm{SO}_{2}$ and $\mathrm{NO}_{2}$ together (Bist et al. 2004). According to Ribeiro et al. (2017), this heterogeneity seems related, at least for some changes, to differences in pollutants $\left(\mathrm{NO}_{2}\right.$ and $\left.\mathrm{O}_{3}\right)$ and interspecies variations. In another investigation, the $\mathrm{O}_{3}$ effects on Pinus pollen allergenicity have been reported (GarcíaGallardo et al. 2013), where the highest levels of specific $\mathrm{IgE}$ were found with highest $\mathrm{O}_{3}$ levels $\left(45.90 \mu \mathrm{g} / \mathrm{m}^{3}\right)$ but with lower values for other pollutants. It may be determined that pollen allergenicity and viability in some pollen type 

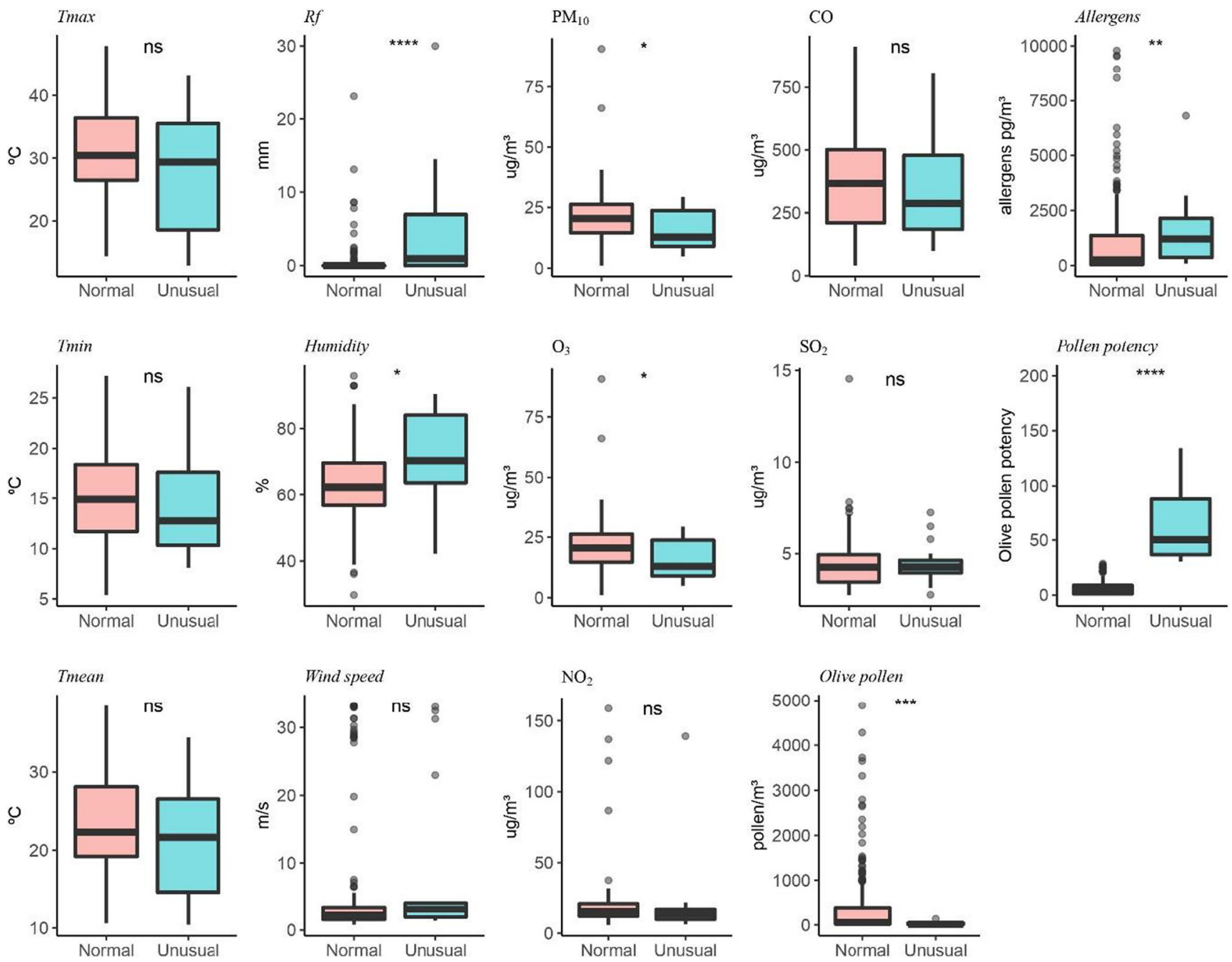

Fig. 5 Comparison between main weather parameters and pollutants in normal and unusual episodes recorded during olive pollen season. $T$ test was used $* * * * p<0.05 ; * * * p<0.001 ; * * p<0.0001 ; * p<0.00001$

increased when vegetation is under elevated $\mathrm{O}_{3}$ conditions (Pasqualini et al. 2011). In our study, both $\mathrm{O}_{3}$ and $\mathrm{PM}_{10}$ seem to have some negative influence on the allergen concentration detected during unusual episodes. One possible cause of this correlation could be that the allergens transported by pollutants (polluen) are not well detected by the immunological test carried out, because they change in some way their protein structure and/or post-translational modifications affecting allergen recognition. In this regards, Rogerieux et al. (2007) detected a decrease in allergen concentration exposing pollen under gaseous pollutants $\left(\mathrm{O}_{3}\right.$ and $\left.\mathrm{NO}_{2}\right)$ during only $4 \mathrm{~h}$. Moreover, both $\mathrm{O}_{3}$ and $\mathrm{PM}_{10}$ could be the reflection of rainy days with low amount of particles in the air, as $\mathrm{O}_{3}$ is especially low during cloudy days. Regarding $\mathrm{NO}_{2}$, a study showed that its influence depends on the type of analyzed pollen (Chassard et al. 2015), perhaps because the exposure of pollen grains to other pollutants changes its structure (Ribeiro et al. 2017).

According to these statements, it is important to study the effect of all the pollutants at the same time, not independently, since the increase of one pollutant affects the plants in more or less virulence according to the amount of other contaminant particles in the atmosphere.

Several studies in urban-polluted air (Ghiani et al. 2012; Wang et al. 2010) showed that some airborne antigens were mainly adsorbed to combustion particles which can thus fly as depots on diesel exhaust particles (DEP) generated from transportation (Namork et al. 2006). They can also be associated with the presence of rainwater in polluted zones (Wang et al. 2013). Our results showed also an important and significant correlation between aeroallergens and humidity. The effect of humidity on pollen is supposed to facilitate the release of cytoplasmic granules and allergens (Buters et al. 2015; D'Amato et al. 2010). However, the humidity causes the deposition of pollen grains as they increase in weight (Barnes et al. 2001; Bartková-Ščevková 2003), explaining the rise in allergens per pollen detected. Moreover, pollen grains under extreme conditions could produce more allergens as a response to make sure pollination (Moreno-Grau et al., 2016; 

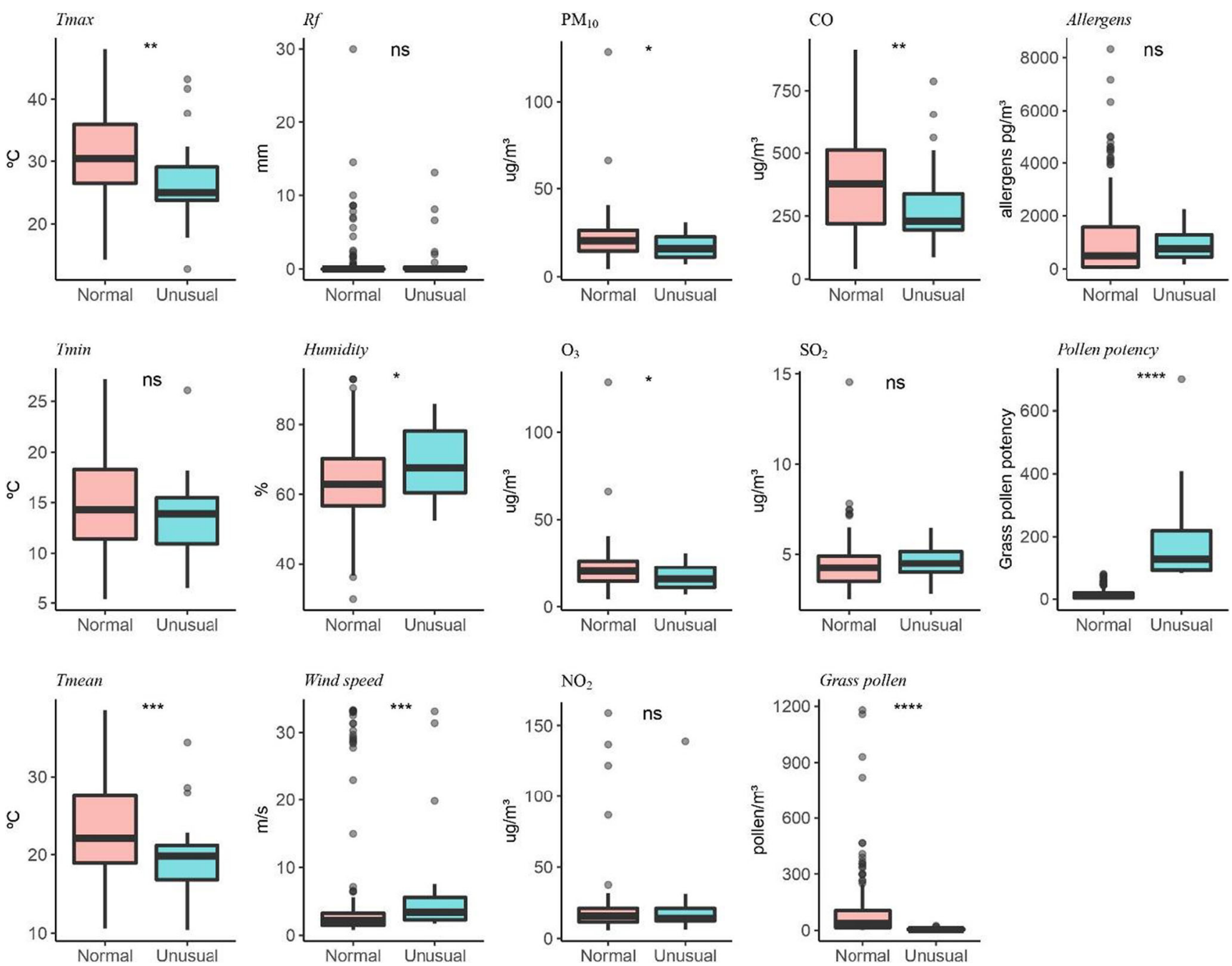

Fig. 6 Comparison of main weather parameters and pollutants in normal and unusual episodes recorded during grass pollen season. $T$ test was used $* * * * p<0.05 ; * * * p<0.001 ; * * p<0.0001 ; * p<0.00001$

Plaza et al., 2016a). In the particular case of grasses, there is a sequence in the PAP depending on the species, and this can be observed in significant differences in seasonal variables such as temperature (Bruffaerts et al., 2018; García-Mozo, 2017; Ščevková et al., 2020).

Additionally, like temperature variations just as barometric ones are important in pollen release and air particle interactions, water is also a main point, specifically in inner pollen subparticle dispersion. According to Schäppi et al. (1999), light rain increases the dispersion by $20 \%$, since it modifies shape and size of pollen. Depending on pollen season and meteorological conditions, the water content in pollen grains will be intensely influenced. On the other hand, the relative effect of the rainfall washout on the air pollutant concentrations results in a decrease of $\mathrm{PM}_{10}, \mathrm{SO}_{2}$, and $\mathrm{CO}$ in the atmosphere, while $\mathrm{NO}_{2}$ and $\mathrm{O}_{3}$ may increase due to opposing influences of lightning-generation or vertical mixing from the troposphere (Yoo et al., 2014).
Even with the positive tendency in the incidence of allergic sensitization in urban places, the factors that justify this phenomenon have not been settled so far. Though, accumulating evidence shows that climate change and pollutants seem to play a part as vegetal stressors, altering the allergenic potential of pollen particles. Their implication in allergy illnesses is previously described in some studies for different regions and pollen types (Bacsi et al. 2006; Kim et al., 2015, 2016). It has been shown that their presence in the air increases the aeroallergen bioavailability. It is important to consider that pollutants might be pollen allergy-initiating and/or facilitating by themselves. Although associations between air pollution and airborne pollen charge are still debated (AnnesiMaesano et al. 2012), experimental works seem to demonstrate that combined effects of atmospheric pollutants and pollen are very unfavorable to allergic people.

Air pollution coincides with the existing increase in the prevalence of allergic diseases (Motta et al. 2006). Our results indicate that the pollutants may not affect the concentration of 
allergens in the air in a city like Cordoba, where pollution values are not very high (Junta Andalucia, 2014). Nevertheless, it seems that there is consensus between different studies where there is a positive correlation between the increase of pollutants and the increase of symptoms in the population (Bacsi et al. 2006; Burte et al. 2018; Cabrera et al. 2018; Kim et al. 2016).

To better understand the complex relations between vegetation, atmosphere, mechanisms of pollen rupture, and weather conditions just as the effect on health, we need more standardized studies with different pollen types and diverse pollutant doses. Since, pollen response is not equal in front of the pollution and there are evidences that its susceptibility to pollutants varies according to the plant species.

Moreover, the effects of air pollution on the dispersion and allergenicity of these subparticles are awhile not clearly explained, because of the extremely complex pollen-pollutant interactions.

Therefore, it would be convenient to take into consideration this stress-induced increase in pollen particles by pollutants as a reliable environmental factor in respiratory allergy epidemiology.

\section{Conclusion}

Outdoor aeroallergen is mostly due to pollen, but the relative humidity in the air could increase amount of allergens per pollen. Unusual episodes occur in Córdoba during rainy days with high relative humidity, decreasing pollen concentration, $\mathrm{O}_{3}$ and $\mathrm{PM}_{10}$.

Attending to our results, pollutants do not affect the amount of allergens per pollen in the studied city. Even if different pollutants show a vague relationship with the allergenic content of pollen, this relationship seems to be a casual effect of the leading role of some meteorological parameters. Further researches should shed light on the molecular interaction between pollutants and pollen grains, integrated with possible negative influenced in real-life allergic symptoms.

Funding Open Access funding enabled and organized by Projekt DEAL.

Open Access This article is licensed under a Creative Commons Attribution 4.0 International License, which permits use, sharing, adaptation, distribution and reproduction in any medium or format, as long as you give appropriate credit to the original author(s) and the source, provide a link to the Creative Commons licence, and indicate if changes were made. The images or other third party material in this article are included in the article's Creative Commons licence, unless indicated otherwise in a credit line to the material. If material is not included in the article's Creative Commons licence and your intended use is not permitted by statutory regulation or exceeds the permitted use, you will need to obtain permission directly from the copyright holder. To view a copy of this licence, visit http://creativecommons.org/licenses/by/4.0/.

\section{References}

Abou Chakra OR, Sutra J-P, Demey Thomas E, Vinh J, Lacroix G, Poncet P, Senechal H (2012) Proteomic analysis of major and minor allergens from isolated pollen cytoplasmic granules. J Proteome Res 11:1208-1216

Junta Andalucia (2014). Informe de Calidad del Aire Ambiente.

Anderson HR, Favarato G, Atkinson RW (2013) Long-term exposure to air pollution and the incidence of asthma: meta-analysis of cohort studies. Air Qual Atmos Health 6:47-56

Annesi-Maesano I (2016) United Nations Climate Change Conferences: COP21 a lost opportunity for asthma and allergies and preparing for COP22. J Allergy Clin Immunol 138:57-58

Annesi-Maesano I, Rouve S, Desqueyroux H, Jankovski R, Klossek J-M, Thibaudon M, Demoly P, Didier A (2012) Grass pollen counts, air pollution levels and allergic rhinitis severity. Int Arch Allergy Immunol 158:397-404

Arilla MC, Eraso E, Ibarrola I, Algorta J, Martínez A, Asturias JA (2002) Monoclonal antibody-based method for measuring olive pollen major allergen Ole e 1. Ann Allergy Asthma Immunol 89:83-89

Arilla MC, Ibarrola I, Mir A, Monteseirin J, Conde J, Martínez A, Asturias JA (2005) Development of a sandwich-type ELISA for measuring Pla a 1, the major allergen of Platanus acerifolia pollen. Int Arch Allergy Immunol 138:127-133

Arilla MC, González-Rioja R, Ibarrola I, Mir A, Monteseirin J, Conde J, Martinez A, Asturias JA (2006) A sensitive monoclonal antibodybased enzyme-linked immunosorbent assay to quantify Parietaria judaica major allergens, Par j 1 and Par j 2. Clin Exp Allergy 36: $87-93$

Bacsi A, Choudhury BK, Dharajiya N, Sur S, Boldogh I (2006) Subpollen particles: carriers of allergenic proteins and oxidases. J Allergy Clin Immunol 118:844-850

Barnes C, Pacheco F, Landuyt J, Hu F, Portnoy J (2001) The effect of temperature, relative humidity and rainfall on airborne ragweed pollen concentrations. Aerobiologia 17:61-68

Bartková-Ščevková J (2003) The influence of temperature, relative humidity and rainfall on the occurrence of pollen allergens (Betula, Poaceae, Ambrosia artemisiifolia) in the atmosphere of Bratislava (Slovakia). Int J Biometeorol 48:1-5

Bartra J, Mullol J, Del Cuvillo A, Dávila I, Ferrer M, Jáuregui I, Montoro J, Sastre J, Valero A (2007) Air pollution and allergens. J Investig Allergol Clin Immunol 17:3-8

Behrendt H, Becker WM, Fritzsche C, Sliwa-Tomczok W, Tomczok J, Friedrichs KH, Ring J (1997) Air pollution and allergy: experimental studies on modulation of allergen release from pollen by air pollutants. Int Arch Allergy Immunol 113:69-74

Berger M, Bastl K, Bastl M, Dirr L, Hutter H-P, Moshammer H, Gstöttner W (2020) Impact of air pollution on symptom severity during the birch, grass and ragweed pollen period in Vienna, Austria: importance of O3 in 2010-2018. Environ Pollut 263:114526

Bist A, Pandit T, Bhatnagar AK, Singh AB (2004) Variability in protein content of pollen of Castor bean (Ricinus communis) before and after exposure to the air pollutants SO and NO. Grana 43:94-100

Bruffaerts N, De Smedt T, Delcloo A, Simons K, Hoebeke L, Verstraeten C, Van Nieuwenhuyse A, Packeu A, Hendrickx M (2018) Comparative long-term trend analysis of daily weather conditions with daily pollen concentrations in Brussels, Belgium. Int $\mathbf{J}$ Biometeorol 62:483-491

Burte E, Leynaert B, Bono R, Brunekreef B, Bousquet J, Carsin A-E, De Hoogh K, Forsberg B, Gormand F, Heinrich J et al (2018) Association between air pollution and rhinitis incidence in two European cohorts. Environ Int 115:257-266

Buters J, Prank M, Sofiev M, Pusch G, Albertini R, Annesi-Maesano I, Antunes C, Behrendt H, Berger U, Brandao R, Celenk S, Galan C, Grewling Ł, Jackowiak B, Kennedy R, Rantio-Lehtimäki A, Reese 
G, Sauliene I, Smith M, Thibaudon M, Weber B, Cecchi L (2015) Variation of the group 5 grass pollen allergen content of airborne pollen in relation to geographic location and time in season. $\mathrm{J}$ Allergy Clin Immunol 136:87-95

Cabrera M, Garzón BG, Moreno SG, Subiza J (2018) Relationship between air pollution, meteorological factors and grass pollen counts, with seasonal allergic rhinitis in Madrid (1996 and 2009). J Investig Allergol Clin Immunol 0-0.

Cecchi L, Annesi-Maesano I, D'Amato G (2017) News on climate change, air pollution, and allergic triggers of asthma. J Investig Allergol Clin Immunol 28:91-97

Chassard G, Choël M, Gosselin S, Vorng H, Petitprez D, Shahali Y, Tsicopoulos A, Visez N (2015) Kinetic of NO2 uptake by Phleum pratense pollen: chemical and allergenic implications. Environ Pollut 196:107-113

Chehregani A, Kouhkan F (2008) Diesel exhaust particles and allergenicity of pollen grains of Lilium martagon. Ecotoxicol Environ Saf 69:568-573

Chen Y, Han L, Zhou Y, Yang L, Guo Y-S (2020) Artemisia pollen extracts exposed to diesel exhaust enhance airway inflammation and immunological imbalance in asthmatic mice model. IAA 181: 342-352

Costa AR, Galveias A, Arriegas R, Abreu I, Ribeiro H, Antunes CM (2019) Atmospheric pollutants NO2 and O3 enhance allergenic potential of Dactylis glomerata pollen

Crouse DL, Peters PA, Hystad P, Brook JR, van Donkelaar A, Martin RV, Villeneuve PJ, Jerrett M, Goldberg MS, Pope CA III (2015) Ambient PM2. 5, O3, and $\mathrm{NO} 2$ exposures and associations with mortality over 16 years of follow-up in the Canadian Census Health and Environment Cohort (CanCHEC). Environ Health Perspect 123:1180

D'Amato G, Cecchi L, Bonini S, Nunes C, Annesi-Maesano I, Behrendt H, Liccardi G, Popov T, van Cauwenberge P (2007) Allergenic pollen and pollen allergy in Europe. Allergy 62:976-990

D'Amato G, Cecchi L, D'amato M, Liccardi G et al (2010) Urban air pollution and climate change as environmental risk factors of respiratory allergy: an update. J Investig Allergol Clin Immunol 20:95102

D'Amato G, Holgate ST, Pawankar R, Ledford DK, Cecchi L, Al-Ahmad M, Al-Enezi F, Al-Muhsen S, Ansotegui I, Baena-Cagnani CE et al (2015) Meteorological conditions, climate change, new emerging factors, and asthma and related allergic disorders. A statement of the World Allergy Organization. World Allergy Organization Journal 8:25

D'Amato G, Vitale C, D'amato M, Cecchi L, Liccardi G, Molino A, Vatrella A, Sanduzzi A, Maesano C, Annesi-Maesano I (2016) Thunderstorm-related asthma: what happens and why. Clin Exp Allergy 46:390-396

Depciuch J, Kasprzyk I, Roga E, Parlinska-Wojtan M (2016) Analysis of morphological and molecular composition changes in allergenic Artemisia vulgaris L. pollen under traffic pollution using SEM and FTIR spectroscopy. Environ Sci Pollut Res 23:23203-23214

Duhoux E (1982) Mechanism of exine rupture in hydrated taxoid type of pollen. Grana 21:1-7

Eguiluz-Gracia I, Mathioudakis AG, Bartel S, Vijverberg SJH, Fuertes E, Comberiati P, Cai YS, Tomazic PV, Diamant Z, Vestbo J, et al (2020) The need for clean air: the way air pollution and climate change affect allergic rhinitis and asthma. Allergy $n / a$

Emberlin J (1995) Plant allergens on pauci-micronic airborne particles. Clin Exp Allergy 25:202-205

Fernández-Navarro P, García-Pérez J, Ramis R, Boldo E, López-Abente G (2017) Industrial pollution and cancer in Spain: an important public health issue. Environ Res 159:555-563

Galán C, Smith M, Thibaudon M, Frenguelli G, Oteros J, Gehrig R, Berger U, Clot B, Brandao R, group, E.Q. working et al (2014)
Pollen monitoring: minimum requirements and reproducibility of analysis. Aerobiologia 30:385-395

Galán C, Alcázar P, Oteros J, García-Mozo H, Aira M, Belmonte J, de la Guardia CD, Fernández-González D, Gutierrez-Bustillo M, Moreno-Grau S et al (2016) Airborne pollen trends in the Iberian Peninsula. Sci Total Environ 550:53-59

Galán C, Ariatti A, Bonini M, Clot B, Crouzy B, Dahl A, FernandezGonzález D, Frenguelli G, Gehrig R, Isard S, Levetin E, Li DW, Mandrioli P, Rogers CA, Thibaudon M, Sauliene I, Skjoth C, Smith M, Sofiev M (2017) Recommended terminology for aerobiological studies. Aerobiologia 33:293-295

García-Gallardo MV, Algorta J, Longo N, Espinel S, Aragones A, Lombardero M, Bernaola G, Jauregui I, Aranzabal A, Albizu MV (2013) Evaluation of the effect of pollution and fungal disease on Pinus radiata pollen allergenicity. Int Arch Allergy Immunol 160: 241-250

García-Mozo H (2017) Poaceae pollen as the leading aeroallergen worldwide: a review. Allergy 72:1849-1858

Ghiani A, Aina R, Asero R, Bellotto E, Citterio S (2012) Ragweed pollen collected along high-traffic roads shows a higher allergenicity than pollen sampled in vegetated areas. Allergy 67:887-894

Gruzieva O, Bellander T, Eneroth K, Kull I, Melén E, Nordling E, van Hage M, Wickman M, Moskalenko V, Hulchiy O, Pershagen G (2012) Traffic-related air pollution and development of allergic sensitization in children during the first 8 years of life. J Allergy Clin Immunol 129:240-246

Guarnieri M, Balmes JR (2014) Outdoor air pollution and asthma. Lancet 383:1581-1592

Hirst J (1952) An automatic volumetric spore trap. Ann Appl Biol 39: $257-265$

Jenerowicz D, Silny W, Danczak-Pazdrowska A, Polanska A, OsmolaMankowska A, Olek-Hrab K (2012) Environmental factors and allergic diseases.Ann Agric Environ Med 19(3):475-81

Kanter U, Heller W, Durner J, Winkler JB, Engel M, Behrendt H, Holzinger A, Braun P, Hauser M, Ferreira F (2013) Molecular and immunological characterization of ragweed (Ambrosia artemisiifolia L.) pollen after exposure of the plants to elevated ozone over a whole growing season. PLoS One 8:e61518

Kim K-H, Kabir E, Kabir S (2015) A review on the human health impact of airborne particulate matter. Environ Int 74:136-143

Kim H, Park Y, Park K, Yoo B (2016) Association between pollen risk indexes, air pollutants, and allergic diseases in Korea. Osong Public Health Res Perspect 7(3):172-179

Laaidi M, Laaidi K, Besancenot J-P (2002) Synergie entre pollens et polluants chimiques de l'air: les risques croisés. Environ Risque Sante 1:42-49

Laaidi M, Chinet T, Aegerter P (2011) Allergies au pollen, pollution et climat: revue de la littérature. Rev Fr Allergol 51:622-628

Lacroix G (2005) Allergies respiratoires, pollens et polluants. Arch Mal Prof Enviro 66:584-591

Lu S, Ren J, Hao X, Liu D, Zhang R, Wu M, Yi F, Lin J, Shinich Y, Wang Q (2014) Characterization of protein expression of Platanus pollen following exposure to gaseous pollutants and vehicle exhaust particles. Aerobiologia 30:281-291

Malayeri BE, Noori M, Jafari M (2012) Using the pollen viability and morphology for fluoride pollution biomonitoring. Biol Trace Elem Res 147:315-319

McMichael AJ, Woodruff RE, Hales S (2006) Climate change and human health: present and future risks. Lancet 367:859-869

Moreno-Grau S, Elvira-Rendueles B, Moreno J, García-Sánchez A, Vergara N, Asturias JA, Arilla M, Ibarrola I, Seoane-Camba JA, Suárez-Cervera M (2006) Correlation between Olea europaea and Parietaria judaica pollen counts and quantification of their major allergens Ole e 1 and Par j 1-Par j 2. Ann Allergy Asthma Immunol 96:858-864 
Moreno-Grau S, Aira MJ, Elvira-Rendueles B, Fernández-González M, Fernández-González D, García-Sánchez A, Martínez-García MJ, Moreno JM, Negral L, Vara A (2016) Assessment of the Olea pollen and its major allergen Ole e 1 concentrations in the bioearosol of two biogeographical areas. Atmos Environ 145:264-271

Motta AC, Marliere M, Peltre G, Sterenberg P, Lacroix G (2006) Trafficrelated air pollutants induce the release of allergen-containing cytoplasmic granules from grass pollen. Int Arch Allergy Immunol 139: 294-298

Mousavi F, Shahali Y, Pourpak Z, Majd A, Ghahremaninejad F (2019) Year-to-year variation of the elemental and allergenic contents of Ailanthus altissima pollen grains: an allergomic study. Environ Monit Assess 191:362

Naas O, Mendez M, Quijada M, Gosselin S, Farah J, Choukri A, Visez N (2016) Chemical modification of coating of Pinus halepensis pollen by ozone exposure. Environ Pollut 214:816-821

Naclerio R, Ansotegui IJ, Bousquet J, Canonica GW, D'Amato G, Rosario N, Pawankar R, Peden D, Bergmann K-C, Bielory L et al (2020) International expert consensus on the management of allergic rhinitis (AR) aggravated by air pollutants: impact of air pollution on patients with AR: current knowledge and future strategies. World Allergy Organ J 13:100106

Namork E, Johansen BV, Løvik M (2006) Detection of allergens adsorbed to ambient air particles collected in four European cities. Toxicol Lett 165:71-78

Nolan C, Overpeck JT, Allen JRM, Anderson PM, Betancourt JL, Binney HA, Brewer S, Bush MB, Chase BM, Cheddadi R, Djamali M, Dodson J, Edwards ME, Gosling WD, Haberle S, Hotchkiss SC, Huntley B, Ivory SJ, Kershaw AP, Kim SH, Latorre C, Leydet M, Lézine AM, Liu KB, Liu Y, Lozhkin AV, McGlone MS, Marchant RA, Momohara A, Moreno PI, Müller S, Otto-Bliesner BL, Shen C, Stevenson J, Takahara H, Tarasov PE, Tipton J, Vincens A, Weng C, Xu Q, Zheng Z, Jackson ST (2018) Past and future global transformation of terrestrial ecosystems under climate change. Science 361:920-923

Noyes PD, McElwee MK, Miller HD, Clark BW, Van Tiem LA, Walcott KC, Erwin KN, Levin ED (2009) The toxicology of climate change: environmental contaminants in a warming world. Environ Int 35: 971-986

Oduber F, Calvo AI, Blanco-Alegre C, Castro A, Vega-Maray AM, Valencia-Barrera RM, Fernández-González D, Fraile R (2019) Links between recent trends in airborne pollen concentration, meteorological parameters and air pollutants. Agric For Meteorol 264: $16-26$

Oh J-W (2018) Pollen allergy in a changing world: a guide to scientific understanding and clinical practice (Springer)

Oteros J, García-Mozo H, Alcázar P, Belmonte J, Bermejo D, Boi M, Cariñanos P, de la Guardia CD, Fernández-González D, GonzálezMinero F et al (2015) A new method for determining the sources of airborne particles. J Environ Manag 155:212-218

Ouyang Y, Xu Z, Fan E, Li Y, Zhang L (2016) Effect of nitrogen dioxide and sulfur dioxide on viability and morphology of oak pollen. International Forum of Allergy \& Rhinology 6:95-100

Pasqualini S, Tedeschini E, Frenguelli G, Wopfner N, Ferreira F, D'Amato G, Ederli L (2011) Ozone affects pollen viability and NAD (P) H oxidase release from Ambrosia artemisiifolia pollen. Environ Pollut 159:2823-2830

Pazmandi K, Kumar BV, Szabo K, Boldogh I, Szoor A, Vereb G, Veres A, Lanyi A, Rajnavolgyi E, Bacsi A (2012) Ragweed subpollen particles of respirable size activate human dendritic cells. PLoS One 7:e52085

Peden D, Reed CE (2010) Environmental and occupational allergies. J Allergy Clin Immunol 125:S150-S160

Peltre G (1998) Inter-relationship between allergenic pollens and air pollution. Allerg Immunol (Paris) 30:324-326
Plaza M, Alcázar P, Hernández Ceballos MÁ, Galán C (2016a) Mismatch in aeroallergens and airborne grass pollen concentrations. Atmos Environ 144:361-369

Plaza MP, Alcázar P, Galán C (2016b) Correlation between airborne Olea europaea pollen concentrations and levels of the major allergen Ole e 1 in Córdoba, Spain, 2012-2014. Int J Biometeorol 60:1841-1847

Plaza MP, Alcázar P, Velasco-Jiménez MJ, Galán C (2017) Aeroallergens: a comparative study of two monitoring methods. Aerobiologia 33:363-373

Provost EB, Chaumont A, Kicinski M, Cox B, Fierens F, Bernard A, Nawrot TS (2014) Serum levels of club cell secretory protein (Clara) and short-and long-term exposure to particulate air pollution in adolescents. Environ Int 68:66-70

R Core Team (2013) R: a language and environment for statistical computing. R Foundation for Statistical Computing, Vienna

Recio M, Picornell A, Trigo MM, Gharbi D, García-Sánchez J, Cabezudo B (2018) Intensity and temporality of airborne Quercus pollen in the southwest Mediterranean area: correlation with meteorological and phenoclimatic variables, trends and possible adaptation to climate change. Agric For Meteorol 250-251:308-318

Reinmuth-Selzle K, Kampf CJ, Lucas K, Lang-Yona N, FröhlichNowoisky J, Shiraiwa M, Lakey PSJ, Lai S, Liu F, Kunert AT, Ziegler K, Shen F, Sgarbanti R, Weber B, Bellinghausen I, Saloga J, Weller MG, Duschl A, Schuppan D, Pöschl U (2017) Air pollution and climate change effects on allergies in the Anthropocene: abundance, interaction, and modification of allergens and adjuvants. Environ Sci Technol 51:4119-4141

Rezanejad F (2009) Air pollution effects on structure, proteins and flavonoids in pollen grains of Thuja orientalis L.(Cupressaceae). Grana 48:205-213

Ribeiro H, Costa C, Abreu I, da Silva JCE (2017) Effect of O3 and NO2 atmospheric pollutants on Platanus $\mathrm{x}$ acerifolia pollen: immunochemical and spectroscopic analysis. Sci Total Environ 599:291297

Rodríguez-Rajo FJ, Jato V, González-Parrado Z, Elvira-Rendueles B, Moreno-Grau S, Vega-Maray A, Fernández-González D, Asturias JA, Suárez-Cervera M (2011) The combination of airborne pollen and allergen quantification to reliably assess the real pollinosis risk in different bioclimatic areas. Aerobiologia 27:1-12

Rogerieux F, Godfrin D, Sénéchal H, Motta AC, Marlière M, Peltre G, Lacroix G (2007) Modifications of Phleum pratense grass pollen allergens following artificial exposure to gaseous air pollutants (O3, NO2, SO2). IAA 143:127-134

RStudio Team (2020) RStudio: integrated development for R. RStudio, PBC, Boston, MA URL

Sbihi H, Boutin RC, Cutler C, Suen M, Finlay BB, Turvey SE (2019) Thinking bigger: how early-life environmental exposures shape the gut microbiome and influence the development of asthma and allergic disease. Allergy 74:2103-2115

Ščevková J, Vašková Z, Sepšiová R, Dušička J, Kováč J (2020) Relationship between Poaceae pollen and Phl p 5 allergen concentrations and the impact of weather variables and air pollutants on their levels in the atmosphere. Heliyon 6:e04421

Schäppi GF, Taylor PE, Pain MC, Cameron PA, Dent AW, Staff IA, Suphioglu C (1999) Concentrations of major grass group 5 allergens in pollen grains and atmospheric particles: implications for hay fever and allergic asthma sufferers sensitized to grass pollen allergens. Clin Exp Allergy 29:633-641

Schmidt CW (2016) Pollen overload: seasonal allergies in a changing climate. Environ Health Perspect 124:A70

Sedghy F, Varasteh A-R, Sankian M, Moghadam M (2018) Interaction between air pollutants and pollen grains: the role on the rising trend in allergy. Rep Biochem Mol Biol 6:219-224

Sénéchal H, Visez N, Charpin D, Shahali Y, Peltre G, Biolley J-P, Lhuissier F, Couderc R, Yamada O, Malrat-Domenge A (2015) A 
review of the effects of major atmospheric pollutants on pollen grains, pollen content, and allergenicity. Sci World J 2015:1-29

Shahali Y, Dadar M (2018) Plant food allergy: influence of chemicals on plant allergens. Food Chem Toxicol 115:365-374

Shahali Y, Pourpak Z, Moin M, Zare A, Majd A (2009a) Impacts of air pollution exposure on the allergenic properties of Arizona cypress pollens. In Journal of Physics: Conference Series, (IOP Publishing), p. 012027

Shahali Y, Pourpak Z, Moin M, Mari A, Majd A (2009b) Instability of the structure and allergenic protein content in Arizona cypress pollen. Allergy 64:1773-1779

Shea KM, Truckner RT, Weber RW, Peden DB (2008) Climate change and allergic disease. J Allergy Clin Immunol 122:443-453

Sheehan WJ, Gaffin JM, Peden DB, Bush RK, Phipatanakul W (2017) Advances in environmental and occupational disorders in 2016. J Allergy Clin Immunol 140:1683-1692

Smith M, Emberlin J, Stach A, Rantio-Lehtimäki A, Caulton E, Thibaudon M, Sindt C, Jäger S, Gehrig R, Frenguelli G, Jato V, Rajo FJR, Alcázar P, Galán C (2009) Influence of the North Atlantic Oscillation on grass pollen counts in Europe. Aerobiologia 25:321-332

Sofiev M, Berger U, Prank M, Vira J, Arteta J, Belmonte J, Bergmann KC, Chéroux F, Elbern H, Friese E (2015) MACC regional multimodel ensemble simulations of birch pollen dispersion in Europe. Atmos Chem Phys 15:8115-8130

Soldevilla CG, Gonzalez PC, Teno PA, Vilches ED (2007) Spanish Aerobiology Network (REA): management and quality manual. Publicaciones de La Universidad de Córdoba 1-300

Takahashi Y, Ohashi T, Nagoya T, Sakaguchi M, Yasueda H, Nitta H (2001) Possibility of real-time measurement of an airborne Cryptomeria japonica pollen allergen based on the principle of surface plasmon resonance. Aerobiologia 17:313-318

Tashpulatov AS, Clement P, Akimcheva SA, Belogradova KA, Barinova I, Rakhmawaty FD, Heberle-Bors E, Touraev A (2004) A model system to study the environment-dependent expression of the Bet $\mathrm{v}$ 1a gene encoding the major birch pollen allergen. Int Arch Allergy Immunol 134:1-9
Thomas P, Deutinger P, Heubl G, Strube D, Przybilla B (1996) 143 Influence of gaseous pollutants on pollen viability (PV), germination (PG) and protein release (PR). J Allergy Clin Immunol 97:218

Velasco-Jiménez M, Alcázar P, Domínguez-Vilches E, Galán C (2013) Comparative study of airborne pollen counts located in different areas of the city of Córdoba (south-western Spain). Aerobiologia 29:113-120

Wang Q, Morita J, Nakamura S, Wu D, Gong X, Suzuki M, Miwa M, Nakajima D (2010) Field investigation on modification of Japanese cedar pollen allergen in urban air-polluted area. World Acad Sci Eng Technol 69:624-629

Wang Q, Gong X, Suzuki M, Lu S, Sekiguchi K, Nakajima D, Miwa M (2013) Size-segregated allergenic particles released from airborne Cryptomeria japonica pollen grains during the yellow sand events within the pollen scattering seasons. Asian Journal of Atmospheric Environment (AJAE) 7

WHO (2000) Air quality guidelines for Europe (Copenhagen : WHO Regional Office for Europe)

Yoo J-M, Lee Y-R, Kim D, Jeong M-J, Stockwell WR, Kundu PK, Oh SM, Shin D-B, Lee S-J (2014) New indices for wet scavenging of air pollutants $(\mathrm{O} 3, \mathrm{CO}, \mathrm{NO} 2, \mathrm{SO} 2$, and $\mathrm{PM} 10)$ by summertime rain. Atmos Environ 82:226-237

Zhang Y, Bielory L, Mi Z, Cai T, Robock A, Georgopoulos P (2015) Allergenic pollen season variations in the past two decades under changing climate in the United States. Glob Chang Biol 21:15811589

Ziello C, Sparks TH, Estrella N, Belmonte J, Bergmann KC, Bucher E, Brighetti MA, Damialis A, Detandt M, Galán C, Gehrig R, Grewling L, Gutiérrez Bustillo AM, Hallsdóttir M, KockhansBieda MC, de Linares C, Myszkowska D, Pàldy A, Sánchez A, Smith M, Thibaudon M, Travaglini A, Uruska A, ValenciaBarrera RM, Vokou D, Wachter R, de Weger LA, Menzel A (2012) Changes to airborne pollen counts across Europe. PLoS One 7:e34076

Publisher's note Springer Nature remains neutral with regard to jurisdictional claims in published maps and institutional affiliations. 